\title{
SIMULATION OF ACCELERATION GROUND MOTIONS BY HIERARCHY FAULT MODEL
}

階層断層モデルによる加速度地震動のシミュレーション

\author{
Demin FENG*, Takao NISHIKAWA**, Masayuki KIKUCHI*** and Makoto WATABE**** \\ 馮＼cjkstart徳民, 西川孝夫, 菊地正幸, 渡部 丹”
}

\begin{abstract}
A hierarchy model is studied to simulate acceleration strong motions quantitatively both in time histöries and frequency contents. The hierarchy model is formed by introducing hierarchy property into an earthquake source in addition to the heterogeneity and discontinuity in the rupture process. It is characterized by 1) average stress drop, 2) fault dimension, 3) spatial distribution of the discrete sources, 4) hierarchy order and hierarchy element length ratio. Through simulation studies of acceleration ground motions recorded during the Izu-Hanto-Toho-Oki earthquake on July 9,1989 , present method is found capable to explain the high frequency component up to about $4.0 \mathrm{~Hz}$.
\end{abstract}

Keywords : earthquake source, rupture process, hierarchy model, theoretical seismograms, fault model 地震源, 破壊過程, 階層モデル, 理論地震動, 断層モデル

\section{Introduction}

Significant progress has been made after Housner $(1947)^{1)}$ first characterized strong motion accelerograms by superposition of random pulses which are generated by a swarm of dislocations randomly distributed on a fault plane. For the simplest and yet effective representation of a predicted ground motion, maximum values (acceleration, velocity and displacement), spectral properties, time duration and envelope function are studied by regression analyses related to the earthquake magnitude, the hypocentral distance or epicentral distance and the site factor. This method is very effective to a general view of ground motions where the active fault or the underground structure is unknown.

A great deal of efforts has been made toward a more quantitative prediction of strong ground motion for a potential earthquake fault. Fault models have been successfully applied to generate seismograms analytically, in which ground motions are assumed as the result of the convolution of a source time function accounting for the rupture process, and a Green's function accounting for the wave propagation. Especially, Haskell model ${ }^{21}$, because of its simplicity, has been widely used to analyze long period surface wave records due to large earthquakes and body waves due to moderate earthquakes. High frequency motions by fault model, however, require more detailed information about the rupture process. Several source models, such as asperity model ${ }^{3)}$ and barrier model ${ }^{4)}$ have been proposed to explain the heterogeneity of the mechanical properties in the fault zones, and the discontinuity in the source rupture process. In practice, a stochastic model ${ }^{5 / 7 ?}$ would cover our ignorance of the details of fault zone and rupture process.

Feng et al. (1991 $)^{8) .91}$ proposed the hierarchy fault model to generate broad-band seismograms, based on the concept presented by Fukao \& Furumoto $(1985)^{10}$. The hierarchy model was proved useful to

* Research Engineer, Research Institute, Fujita, Dr. Eng.

** Prof.,' Tokyo Metropolitan Univ., Dr..Eng.

*** Prof., Yokohama City Univ., Dr. Sc.

**** Shimizu Corporation, Dr. Eng.
(株) フジ夕技術研究所 研究員・博士 (工学)

東京都立大学建築学科 教授・博士 (工学)

横浜市立大学文理学部 教授・博士 (理学)

（株）清水建設 専務 - 博士 (工学) 
simulate the velocity records up to $2 \mathrm{~Hz}$ in the former studies. In this paper, we briefly summarize the procedure to use hierarchy model and then, efforts are made toward the simulation of acceleration records.

The method is applied to the Izu-Hanto-Toho-Oki earthquake on July $9,1989\left(M_{J}=5.5\right)$ which were recorded with epicentral distances smaller than $3 \mathrm{~km}$. Effects of parameters such as hierarchy order, hierarchy element length ratio and rupture pattern, on the maximum values, time duration and spectral properties of the synthetic seismograms are discussed. This study is supposed to contribute to the approaches to simulate acceleration strong motions quantitatively both in time histories and frequency contents by the fault model.

\section{Hierarchy Fault Model}

An earthquake source may be described as Fig. 1 schematically. The sketch in the left side represents the source fault, where discontinuity is indicated by the thick line in the central part, the heterogeneity is indicated by the shielded part. The sketch in the right side represents the hierarchy property for a point source. In addition to the heterogeneity in mechanical properties of a fault plane and the discontinuity in a rupture process, hierarchy in earthquake size distribution was reported to play a very important role on the complexity of earthquake source processes. Phenomena directly related to the hierarchy property include magnitude-frequency relation and the magnitude gap.

The frequency of earthquake $N$ is related to seismic magnitude $M$ as $\log N \sim-M$. Moreover, the fault area $S$ is related to the magnitude $M$ as $\log S \sim M$. Therefore, we have a relation $S \cdot N \approx$ constant, which means that the same scale sources cover all fault area. It is very interesting that this relation is suitable for all magnitude levels. Next is the magnitude gap found in an 'earthquake family', in which the difference in magnitude between the largest event and the next largest event is about $1 \sim 1.5$. Same phenomenon was also found in a mainshock-aftershock sequence. The magnitude gap between the main shock and the largest aftershock is about $1 \sim 1.2$ or more.

These phenomena could be explained by the hierarchy model quantitatively. Rupture process described by a hierarchy model is shown in Fig. 2. Ruptures grow by repeating cycles shown in the figure. One fault block (shielded part in the figure) starts to rupture into $1,2, \cdots$. If the number of blocks exceeds some number ( 5 blocks in the figure), a bigger fault block starts to rupture. Eventually the main rupture will start. Length ratio between upper order element and lower order element and rupture pattern are parameters described in the hierarchy model.

The procedure to incorporate the hierarchy property into the fault model is summarized as follows.

In gereral, the seismic displacements observed from an earthquake source can be regarded as the result due to a double couple force ${ }^{11}$. The total displacement at any observation point due to an arbitrary

Discontinuity

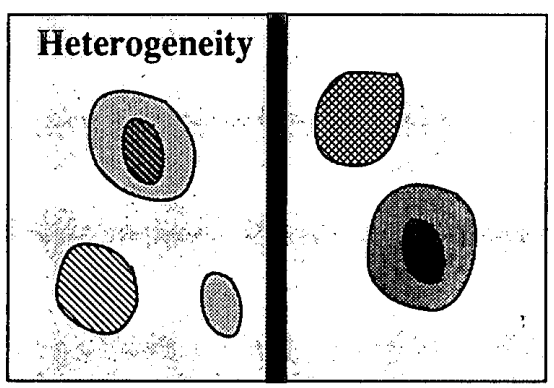

Hierarchy

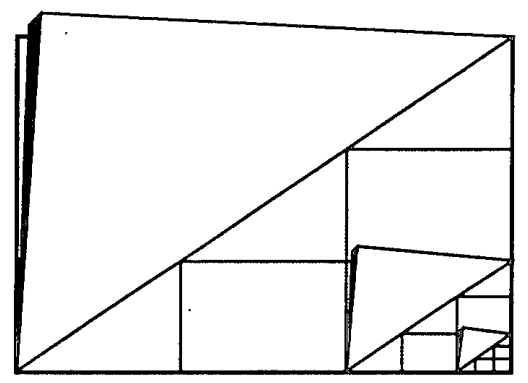

Fig. 1 Properties of discontinuity, heterogeneity and hierarchy to characterize an earthquake source. The sketch in the left side represents the source fault, where discontinuity is indicated by the thick line in the central part, heterogeneity is indicated by the shielded part. The sketch in the right side represents the hierarchy property for a point source. 


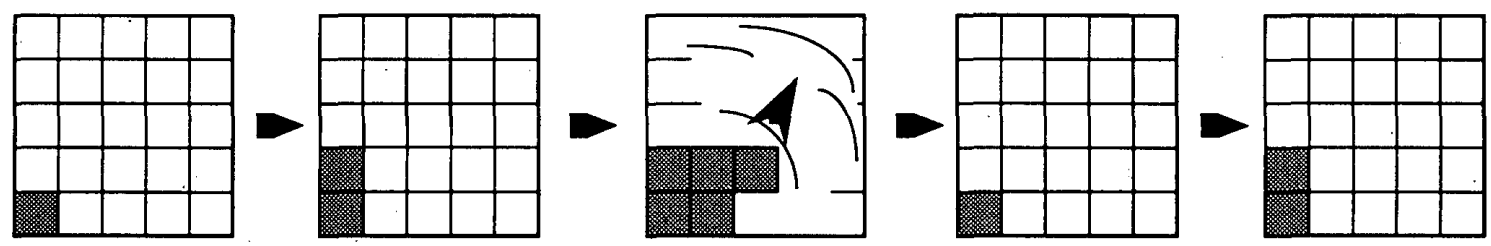

Fig. 2 A model of rupture expansion. Rupture grows by repeating the cycle shown in the figure. A shaded square represents a fault block ruptured. The rupture of all the blocks in the barrier structure at the left three column corresponds to the rupture of a unit block for the barrier structure at the right two column. If, for example, the rupture happens to stop at such a stage as in the most right illustration, a doublet earthquake results. The stage shown in the middle illustration (five blocks broken) then corresponds to the initiation of the main rupture. The preceding stage is regarded as the precursory rupture (after Fukao \& Furumoto, 1985).

distribution of displacement discontinuities on a fault is given as an integral of the moment density tensors over the fault surface convolved with Green's functions. The displacement is given as

$$
u_{n}(x, t)=\int_{-\infty}^{+\infty} d \tau \iint_{F} M_{p q}(\xi, t) \cdot G_{n p, q}(x, t: \xi, \tau) d F(\xi)
$$

$\xi$ : general position on the fault surface $F$;

$M_{p q}:(p q)$ component of the moment tensor;

$G_{n \rho}(x, t: \xi, \tau): x_{n}$-component of the displacement at location $x$ and time $t$ due to a unit impulsive force at location $\xi$ and time $\tau$;

$G_{n \rho, q}(x, t: \xi, \tau):$ the derivative of $G_{n \rho}$ with respect to the source coordinate $\xi_{q}$.

To calculate Green's functions, we assume stratified structures and use wavenumber integration method $^{12)}$, where the dynamic displacements on the free surface are given in terms of reflectiontransmission matrix and discrete wavenumber method. The inversion method proposed by Kikuchi and Kanamori $(1986)^{13)}$ is used to determine source parameters. A rupture process is then described by subevents which are characterized by source parameters, such as the seismic moment, onset time, location, focal mechanism and time history function. The iterative least-squares method is used to give spatial and temporal distribution of slip over the fault areas as follows.

For a set of waveforms observed at $N_{s}$ stations, the 'best' fit solution can be obtained by minimizing the approximation error given by

$$
\Delta=\sum_{j=1}^{N_{s}} \int\left[x_{j}(t)-\sum_{i=1}^{N_{e}} m_{i} w_{j}^{i}\left(t-\tau_{i}, p_{i}\right)\right]^{2} d t
$$

$N_{s}$ : number of stations;

$N_{e}:$ number of subevents ;

$x_{j}(t): j$ th observed waveform;

$m_{i}:$ seismic moment;

$\tau_{i}$ : onset time of $i$ th subevent;

$p_{i}$ : other source parameters of the $i$ th subevent;

$w_{j}^{i}(t, p)$ : Green's function for $j$ th station due to the $i$ th subevent;

Seismic moment of first subevent can be obtained by

$$
m_{1}=\sum_{j=1}^{N_{s}} r_{w x j}\left(\tau_{1}, p_{1}\right) / \sum_{j=1}^{N_{s}} r_{w j}\left(p_{1}\right)
$$

where

$$
\begin{aligned}
& r_{w j}(p)=\int\left[w_{j}^{1}(t, p)\right]^{2} d t \\
& r_{u x j}(\tau, p)=\int w_{j}^{1}(t, p) x_{j}(t+\tau) d t
\end{aligned}
$$

The next subevent is derived from the residual waveforms

$$
x_{j}^{\prime}=x_{j}-m_{1} w_{j}^{1}\left(t-\tau_{1}, p_{1}\right)
$$

The resultant synthetic waveforms after $N_{e}$ iterations, are given by 


$$
y_{j}(t)=\sum_{i=1}^{N_{e}} m_{i} w_{j}^{i}\left(t-\tau_{i}, p_{i}\right)
$$

Hierarchy model is then determined as follows. Results obtained from the analysis of long period motions are used as hierarchy element of the first order. Supposed that $\alpha$ is. the length ratio, then the number of second order hierarchy elements is $\alpha^{-2}$ per each upper order element. The rupture time and moment for the lower order element are respectively $\alpha$ and $\alpha^{-3}$ times of those for the upper order element. Usually, there are $\alpha^{-2(k-1)} k$-th order elements which have a duration $\alpha^{(k-1)}$, moment $\alpha^{-3(k-1)}$ times of those of the first order element. The onset time for the elements is determined by rupture pattern supposed, such as unilateral, circular or random.

Moment rate in Fig. 3 modified for the hierarchy model which will be discussed in section 3 can be expressed as

$$
m_{i}^{\prime}(t)=(1-\alpha)[m_{1}(t)+\cdots+\overbrace{\alpha^{3(k-1)} \sum_{i=1}^{\alpha-2(k-1)} m_{k}\left(t-t_{l k}\right)}^{k \text { th order }}+\cdots]
$$

where

$m_{k}(t)$ : seismic moment of $k$ th order element which could be obtained from Table 1 ;

$t_{l k}$ : onset time of element $l$ in $k$ th order.

The factor $(1-\alpha)$ is used so that the total seismic moment is equivalent to 1 .

Finally, the synthetic waveforms can be obtained by

$$
y_{j}(t)=\sum_{i=1}^{N e} m_{i}^{\prime} w_{j}^{i}\left(t-\tau_{i}, p_{i}\right)
$$

where $m_{i}^{\prime}$ : moderated seismic moment by hierarchy model.

The procedure to use hierarchy model may be as follows.

i) Fault model is used to calculated seismograms as Eq. 6. Parameters such as 1) average stress drop,

2) fault dimensions, 3) spatial and temporal distribution of the discrete sources could be determined from an inversion technique.

ii) Hierarchy property is incorporated into the fault model as Eq. 7, where hierarchy order $(1 \sim 5)$, hierarchy element length ratio $(1 \sim 5)$ and rupture pattern are needed.

\section{Application to the Izu-Hanto-Toho-Oki Earthquake on July 9, 1989}

For a point source, parameters used in the hierarchy model could be determined as follows. If $T_{0}$ is assumed as rupture time, $S_{0}(t)$ is assumed as source time function, then parameters are determined as Table 1. Moment rate, moment acceleration and third deviation of moment are depicted in Fig. 3, which are corresponding to far-field ground displacement, far-field ground velocity and far-field ground acceleration, respectively. Here, moment rate function is assumed as cosine function with a time duration of 6 second and the rupture pattern is assumed as random.

To simulate acceleration ground motions by the present method, it is desirable to use discrete sources determined from velocity ground motions. In order that solutions of the inversion method converge, long period motions are suitable since it is affected little by the detailed rupture process. To exclude site amplification and propagation path effects, it is better to use data recorded near source region.

The Izu-Hanto-Toho-Oki earthquake on July 9, 1989 provides a best set of records. Ito (ITO) and Shiofuki (SOF) are maintained by the Strong Motion Observation Center of the Earthquake Research Institute $^{14)}$, whose epicentral distances are within $3 \mathrm{~km}$. Area map near Ito with the locations of strong motion instruments and focal mechanism are shown in Fig. 4. All seismographs installed at these stations are accelerographs. Ground velocity seismograms are obtained by integrating from acceleration records. Acceleration records are baseline corrected, filtered using a band-pass Chebyshev filter with low-band $f_{l}$ of $0.1 \mathrm{~Hz}$, high-band $f_{h}$ of $10.0 \mathrm{~Hz}$ and stopband $f_{s}$ of $15.0 \mathrm{~Hz}$. The linear accerleration method is used for the integration scheme. To reduce the amplitude of the noise, velocity seismograms 
Table 1 Parameters determined by the hierarchy model

\begin{tabular}{l|c|c|c|c}
\hline & rupture time & seismic moment & time function & number \\
\hline 1st order element & $T_{0}$ & $(1-\alpha)$ & $S_{0}(t)$ & 1 \\
\hline$k$ th order element & $T_{0} \cdot \alpha^{k-1}$ & $\alpha^{3(k-1)}(1-\alpha)$ & $S_{0}\left(t / \alpha^{k-1}\right) \cdot \alpha^{2(k-1)}$ & $\alpha^{-2(k-1)}$ \\
\hline
\end{tabular}

$M^{\prime}(t)$
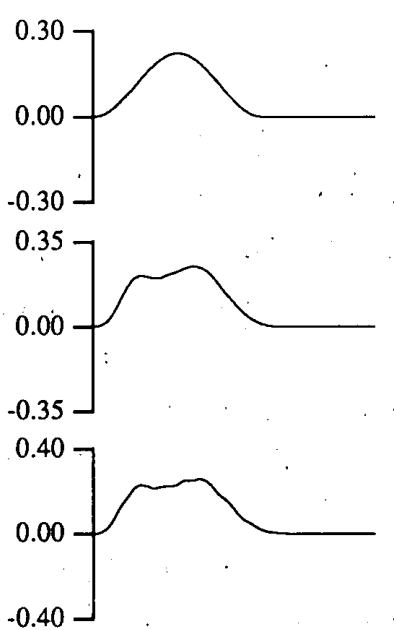

$-0.40$
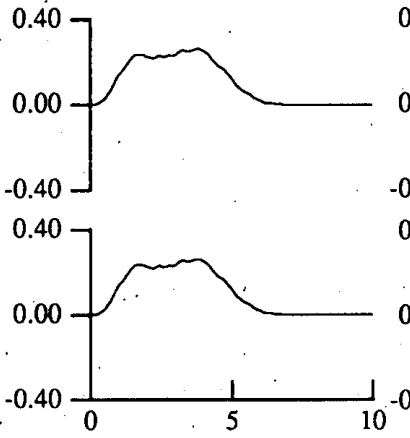
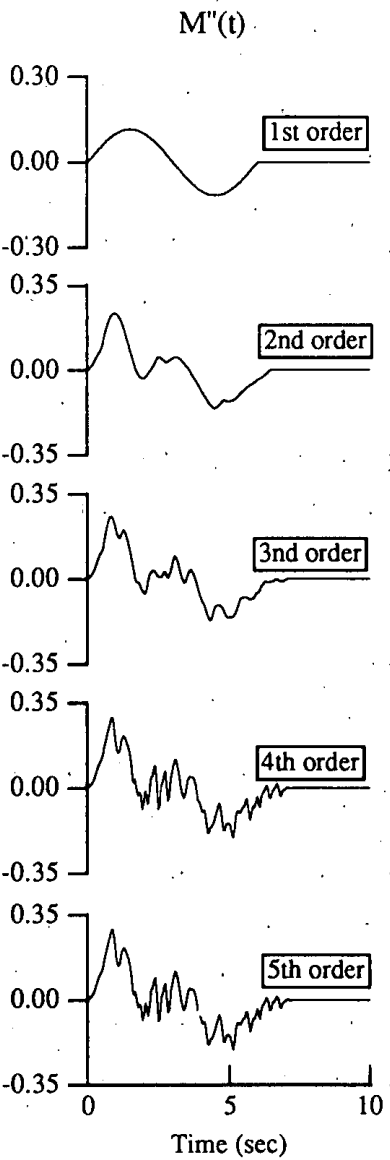

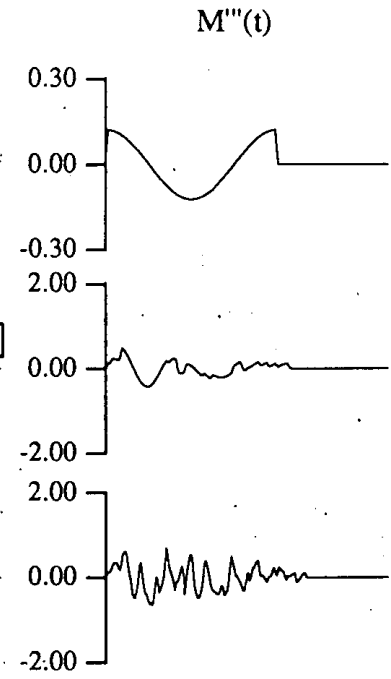

2.00
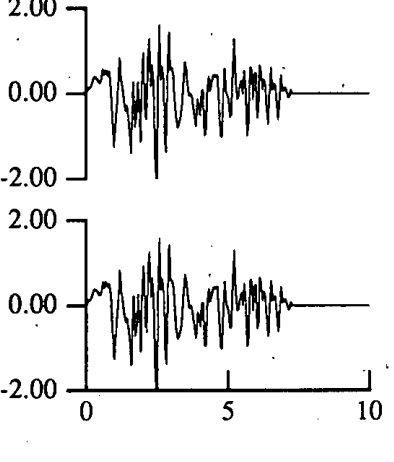
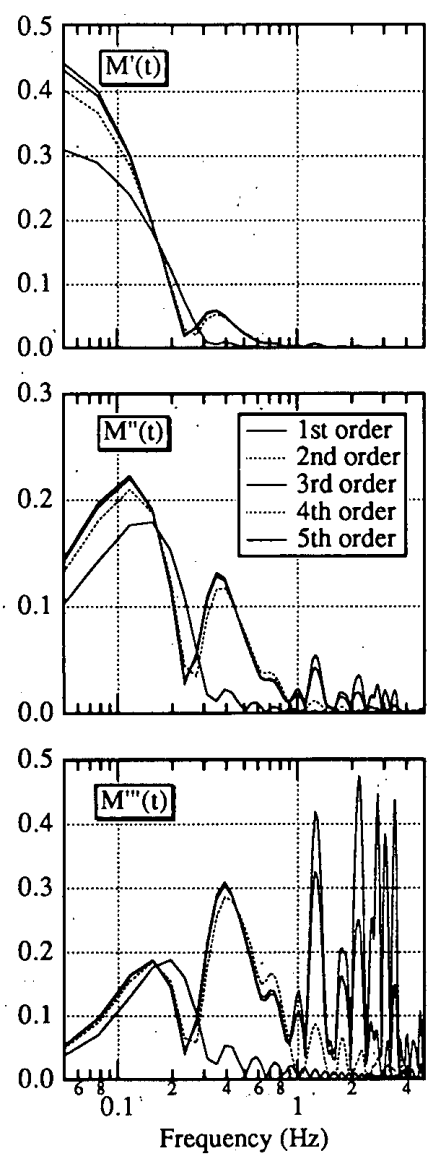

Fig. 3 Moment rate $\propto$ far-field ground displacement (left column); moment acceleration $\propto$ far-field ground velocity (middle column); third deviation of moment $\propto$ far-field ground acceleration (right column) and corresponding Fourier spectra. Moment rate function is assumed as cosine function with a time duration of 6 second. The rupture pattern is assumed as random.

are filtered using a band-pass Chebyshev filter with $f_{l}$ of $0.1 \mathrm{~Hz}, f_{h}$ of $0.5 \mathrm{~Hz}$ and $f_{s}$ of $2.0 \mathrm{~Hz}$. The minimum attenuation in the stopband of all filters is $52 \mathrm{~dB}$.

JMA (Japan Meteorological Agency) and NRCDP (now known as the National Research Institute for Earth Science and Disaster Prevention) proposed slightly different locations, depths and mechanisms that are compared in Table 2. In this study, the model proposed by JMA with discrete sources 5 in the horizontal direction and 4 in depth direction is used. Green's functions are calculated used the earth structure shown in Table $3^{15}$. The moment rate function is assumed as that in Fig. 3 with a time duration of 1.5 second.

The inversion results from velocity ground motions after 2 iterations are shown in Fig. 5. The $P$-wave first motion of the synthetic seismograms did not necessarily coincide with the observed ones, since fault parameters were determined from the overall waveforms in this inversion method. Synthetic waves in EW direction have good agreement with the observed ones since their amplitudes are larger than others'. Generally, there is good agreement in Fourier spectra.

Acceleration seismograms or results by first order hierarchy model are determined only by the inversion results as a differential result of the synthetic velocity waves. In order to examine effects due to parameters such as hierarchy order, hierarchy element length ratio and rupture pattern assumed, 
Table 2 Source parameters given by JMA and NRCDP for the 1989 Izu-Hanto-Toho-Oki earthquake

\begin{tabular}{l|c|c}
\hline & JMA & NRCDP \\
\hline Latitude $\left(^{\circ}\right)$ & 34.992 & 34.994 \\
\hline Longitude $\mathrm{E}\left({ }^{\circ}\right)$ & 139.112 & 139.086 \\
\hline Depth $(\mathrm{km})$ & 3.4 & 6.3 \\
\hline Strike $\left(^{\circ}\right)$ & $\mathrm{N} 86.0 \mathrm{~W}$ & $\mathrm{~N} 102.0 \mathrm{E}$ \\
\hline Dip $\left(^{\circ}\right)$ & $79.0 \mathrm{~N}$ & $79.0 \mathrm{~S}$ \\
\hline Slip $\left(^{\circ}\right)$ & -165.0 & 155.0 \\
\hline Length $(\mathrm{km})$ & 7.0 & 6.0 \\
\hline Width $(\mathrm{km})$ & 4.0 & 5.0 \\
\hline Disp. $(\mathrm{cm})$ & 24.0 & 20.0 \\
\hline Stress-drop (bar) & 31.0 & 26.0 \\
\hline Seism.moment $($ dyne $\cdot \mathrm{cm})$ & $1.8 \times 10^{24}$ & $1.5 \times 10^{24}$ \\
\hline
\end{tabular}

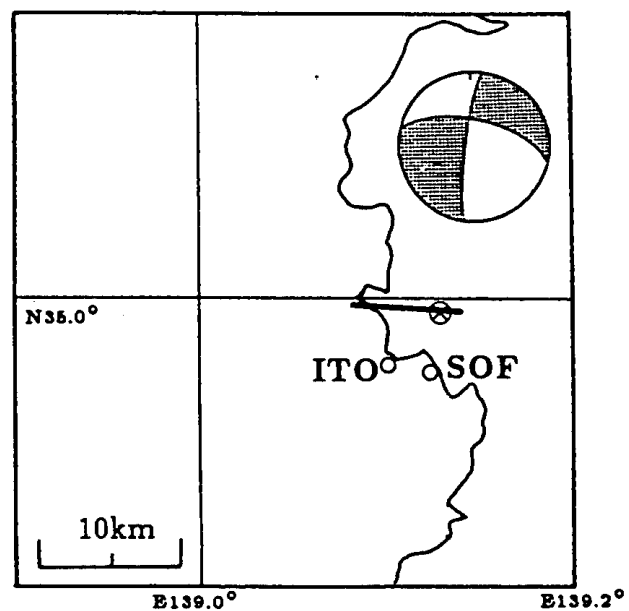

Fig. 4 Area map near Ito with the locations of strong motion instruments and focal mechanism.
Table 3 Velocity structures used to calculate Green's functions (after Takeo, 1991)

\begin{tabular}{l|c|c|c|r|r}
\hline Depth $(\mathrm{km})$ & $\rho\left(\mathrm{g} / \mathrm{cm}^{3}\right)$ & $V_{p}(\mathrm{~km} / \mathrm{s})$ & $V_{s}(\mathrm{~km} / \mathrm{s})$ & $Q_{p}$ & $Q_{s}$ \\
\hline $0.00 \sim 0.50$ & 2.0 & 2.6 & 1.0 & 140 & 70 \\
\hline $0.50 \sim 2.00$ & 2.3 & 4.2 & 1.5 & 200 & 100 \\
\hline $2.00 \sim 3.00$ & 2.6 & 5.3 & 3.0 & 400 & 200 \\
\hline $3.00 \sim 4.00$ & 2.6 & 5.6 & 3.3 & 440 & 220 \\
\hline $4.00 \sim 5.00$ & 2.7 & 5.8 & 3.5 & 460 & 230 \\
\hline $5.00 \sim 6.00$ & 2.7 & 6.0 & 3.6 & 480 & 240 \\
\hline $6.00 \sim 19.0$ & 2.8 & 6.1 & 3.7 & 500 & 250 \\
\hline $19.0 \sim 30.0$ & 3.0 & 6.8 & 3.9 & 520 & 260 \\
\hline $30.0 \sim \infty$ & 3.3 & 7.8 & 4.5 & 1000 & 500 \\
\hline
\end{tabular}

results for rupture pattern circular and random are shown in Figs. 6 and 7, respectively, where source parameters were determined from velocity waveforms. Time histories are shown in the order of length ratio $1 / 2,1 / 3,1 / 4$ and hierarchy order 2 or 3 within one length ratio. The hierarchy order would be determined accorded to the Nyquist frequency and the frequency range of interest referred to the time duration shown Table 1. As frequency contents become richer with the increase of hierarchy order, only Fourier spectra of the last hierarchy order $(=3)$ are shown. Compared with the observed acceleration seismograms, synthetic ones have smaller peak values and have good agreement up to only about $1.0 \mathrm{~Hz}$ in frequency contents. Thus, the complexity waveforms could not be found in the synthetic seismograms.
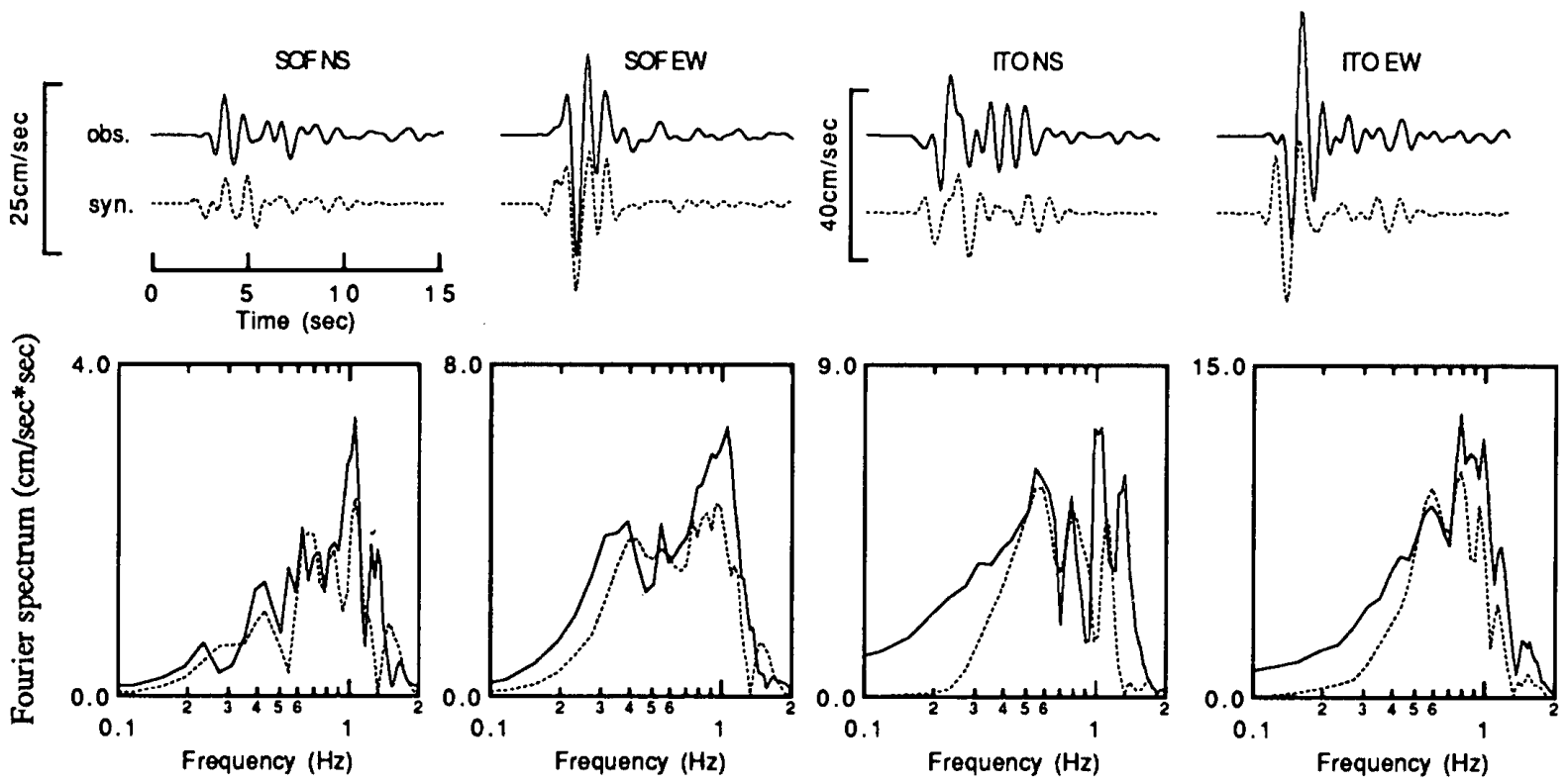

Fig. 5 Comparison of the observed velocity seismograms (solid line) with synthetic ones (broken line) calculated by the inversion method after 2 iterations. The start time is $11: 09: 10$. The Earth model used to calculate Green's functions is shown in Table 3. The moment rate function used is the same one as in Fig. 3 with a time duration of 1.5 second. The observed records are filtered using a band-pass Chebyshev filter with $f_{l}$ of $0.1 \mathrm{~Hz}, f_{h}$ of $1.0 \mathrm{~Hz}$ and $f_{s}$ of $2.0 \mathrm{~Hz}$. 


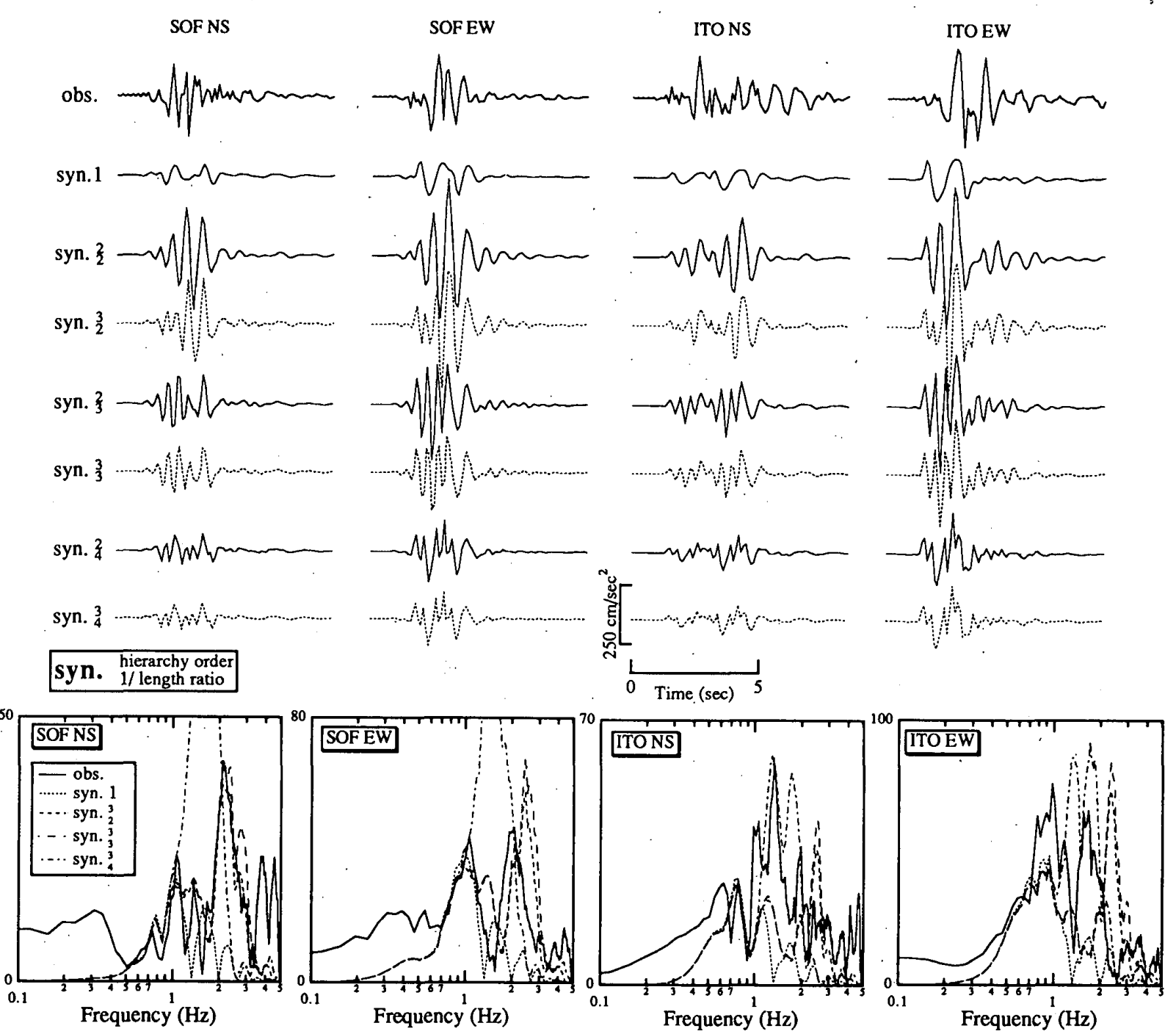

Fig. 6 Comparison of the observed acceleration seismograms with synthetic ones and corresponding Fourier spectra calculated by the hierarchy model. Source parameters were determined from the inversion method. The observed records are filtered using a band-pass Chebyshev filter with $f_{l}$ of $0.1 \mathrm{~Hz}, f_{h}$ of $4.0 \mathrm{~Hz}$ and $f_{s}$ of 4. $5 \mathrm{~Hz}$. The rupture pattern is assumed as circular. The start time is $11: 09: 11.5$.

In general, the maximum value in time histories is proportional to the hierarchy element length ratio, i. e., there is the biggest value in the case where length ratio is $1 / 2$. This is due to the reason that the maximum amplitude of lower order element is $\alpha$ of that of the upper order element and at most two small events occur simultaneously when $\alpha=1 / 3$ or $\alpha=1 / 2$ in the 2 nd hierarchy order. Results by the hierarchy model, where the rupture pattern is assumed as circular would be first discussed. Results where hierarchy order is 3 and length ratio is $1 / 3$ were found better to represent the complexity waveforms and peak values in the observed ones. For Fourier spectra, cases where length ratio is $1 / 2$ or $1 / 3$ were found better at SOF and the case where length ratio is $1 / 4$ was found better at ITO. This would be affected by the inversion results. On the other hand, rupture pattern is preferred to be random rather than circular to represent the average properties. As seen from Fig.7, peak values in time histories have good agreement in the case where hierarchy order is 3 and length ratio is $1 / 3$. For Fourier spectra, the case where length ratio is $1 / 2$ was found to be better one. Solutions best fitted to the entire observed waveforms can be obtained by adjusting the hierarchy model parameters such as hierarchy order, hierarchy element length ratio and rupture pattern. 


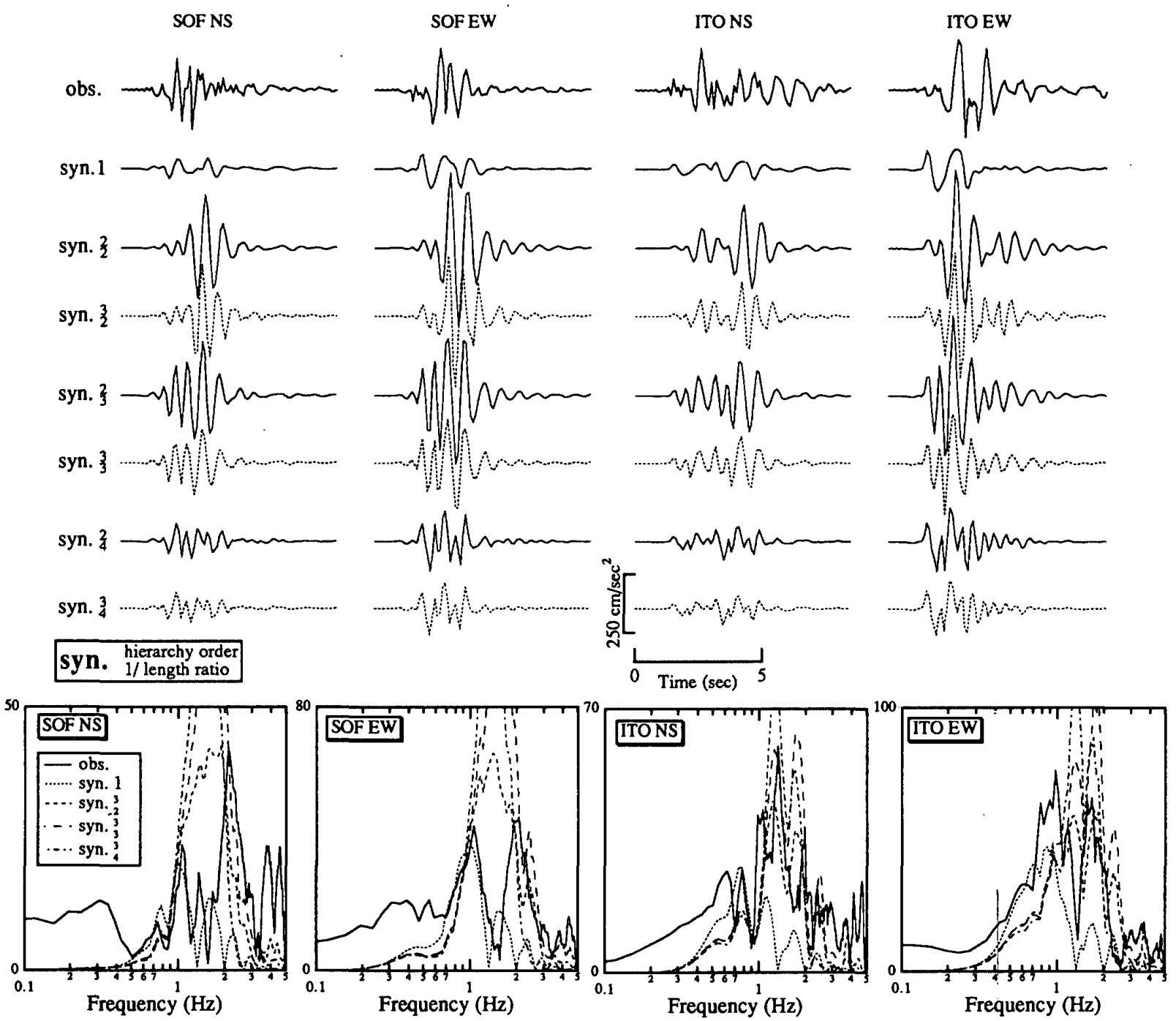

Fig. 7 Comparison of the observed acceleration seismograms with synthetic ones and corresponding Fourier spectra calculated by the hierarchy model. The rupture pattern is assumed as randam. See Fig. 6 for details.

\section{Conclusions}

(1) A new approach is studied to simulate acceleration strong motions quantitatively both in time histories and frequency contents. The hierarchy model is formed by introducing hierarchy property into the earthquake source in addition to the heterogeneity and discontinuity in the rupture process. The hierarchy model is characterized by 1) average stress drop, 2) fault dimension, 3) spatial distribution of the discrete sources, 4) hierarchy order and hierarchy element length ratio. The first three are macroscopic parameters to be estimated by an inversion technique from long period records.

(2) Acceleration ground motions recorded during the Izu-Hanto-Toho-Oki earthquake on July 9, 1989 $\left(M_{J}=5.5\right)$ is simulated by present method. The hierarchy model is found effective to simulate the maximum values, time duration and spectral properties. Acceleration seismograms up to about $4.0 \mathrm{~Hz}$ are well simulated based on the inverșion results obtained from velocity waves up to $1.0 \mathrm{~Hz}$.

(3) For a backward study, one can determine parameters used in the hierarchy model from Fourier spectra. The hierarchy element length ratio could be decided from the ratio between the frequency at which the primary peak value occurred and the frequency at which the second primary peak value in high frequency range occurred. The rupture pattern can be determined from the ratio between the primary peak value and the second primary peak value above.

(4) Through simulation studies, a hierarchy model is found useful to synthesize ground motions over a wide frequency range. There need further studies of various scale eauthquakes for the practical use. 


\section{Acknowledgments}

The authors wish to thank Dr. K. Kudo who kindly provided the records of the Izu-Hanto-Toho-Oki earthquake on July 9, 1989.

\section{References}

1) Housner, G. W. : Characteristics of strong motion earthquakes, Bull. Seism. Soc. Am. 37, pp. 19 31, 1947

2) Haskell, N. A. : Total energy and energy spectral density of elastic wave radiation from propagating faults, Bull. Seism. Soc. Am. 54, pp. $1811 \sim 1841,1964$

3) Kanamori, H. and G. S. Stewart : Seimological aspects of the Guatemala earthquake of February 4, 1976, J. Geophys. Res. 83, pp. $3427 \sim 3434,1978$

4) Aki, K. : Characterization of barriers on an earthquake fault, J. Geophys. Res. 84; pp. 6140 6148, 1979

5) Andrews, D. J. : A stochastic fault model, 2, Time-dependent case, J. Geophys. Res. 86, pp. 10831 10834, 1981

6) Papageorgiou, S. A. and K. Aki : A specific barrier model for the quantitative description of inhomogeneous faulting and the prediction of ground motion. Part I, description of the model, Bull. Seism. Soc. Am. 73, pp.693 722, 1983 (See also Errata, BSSA 74, pp. 794 795, 1984).

7) Koyama, J. : Earthquake source time-function from coherent and incoherent rupture, Tectonophys. 118, pp. 227 242, 1985

8) Feng, D. et al. : A study on synthesization of broad-band seismogrames, Proc. Archit. Inst. Japan Conf., pp. 319 320, 1991 (in Japanese)

9) Feng, D. et al. : Broad-band seismograms by hierarchy model, J. Struct. Eng. 38 B, pp. 71 84, 1992

10) Fukao, Y. and M. Furumoto : Hierarchy in earthquake size distribution, Phys. Earth Planet. Inter. 37, pp. 149 168, 1985

11) Aki, K. and P. G. Richards : Quantitative Seismology Theory and Methods, W. H. Freeman And Company, San Francisco, pp. 50 $\sim 57,1980$

12) Takeo, M. : Near-field synthetic seismograms taking into account the effect of anelasticity, Papers in Meteorology and Geophysics 36, pp. 245 257, 1985 (in Japanese)

13) Kikuchi, M. and H. Kanamori : Inversion of complex body waves-II, Phys. Earth Planet. Inter. 43, pp. 205 222, 1986

14) Kudo, K., M. Sakaue and S. Higashi : Source characteristics of earthquake sequence ocurred at the sea off Ito, July 1989 , as inferred from strong-motion records, Proc. 8th Japan Earth. Eng. Symp. I, pp. 157 162, 1990 (in Japanese)

15). Takeo, M. : Detailed rupture processes of Offshore Ito earthquakes on July 9 , 1989, preceding a submarine volcanic eruption, submitted to J. Geophys. Res., 1991

(Manuscript received December 5, 1991 ; Paper Accepted June 10, 1992) 


\section{和文要約}

1. 序

Housner (1947) $)^{1)}$ が初めて加速度波形を Random 波 形の重ね合わせとして記述して以来, 模擬地震動に関す る研究がかなり蓄積されてきた。より定量的に地震動を 予測するため，断層震源モデルから直接波動計算によっ て長周期地震波を再現しようとする研究が行われるよう になり，かなりの成果を収めている。これに対し，大地 震で観測される実体波は Haskell model ${ }^{2)}$ から期待され る波動よりずっと複雑である。この地震動の複雑さを説 明するために，いくつか改良した震源モデルが提唱され てきた。代表的には，Asperity model ${ }^{13\rangle} と$ Barrier model $^{4)}$ が挙げられる。これらは基本的に断層面上のく いちがいや強度の不均一性と破壊伝播の不連続性を規定 するものといえる。実際に, 確率モデル(5) 7) 用いるこ とによって, 微細な破壊過程を考虑することができる。

Feng et al. (1991 $)^{8), 9)}$ は広帯域模擬地震動を作成する ため，階層モデルを提案した。この方法は地震源の不均 一性, 不連続性に加えて, 階層性も考慮したものである。 具体的には, Inversion 法を用いて, 長周期地震波から 震源過程 (Rupture process) の時空間分布を決めたうえ， これを最上部階層とする階層モデルによって広帯域地震 動を合成するものである。このモデルを用いて，1989 年 7 月 9 日伊豆半島東方沖地震 $\left(M_{J}=5.5\right)$ についてシ ミュレーションを行った。さらに, 最大値, 継続時間, スペクトル特性などについて, 階層モデルのパラメータ である階層階数, 階層要素長さ比と破壊伝播パターンに よる影響を検討した。

\section{2. 階層断層モデル}

図一1に示したような地震源の不均一性，不連続性に 加えて，階層性も導入することによって初めて，微小破 壊から大きな破壊への成長や Magnitude と発生頻度の 関係, 短周期地震動の励起などが統一的にとらえられる。 このモデルに直接関連する物理現象は頻度と Magnitude の関係よ, Magnitude gap などが挙げられる。頻 度 $N$ と断層の面積 $S$ の関係は $S \cdot N \approx$ constant とされて いる。このことは, 同一規模の地震源を寄せ集めると, ちょうど断層面全体が埋めつくされることを意味してい る。この関係は特定の Magnitude だけでなく，色々な Magnitudeごとに幾重にも成立する。また，一つの 'earthquake family'において, 最大イベントの Magnitude と次に大きいイベントの Magnitude の間には1 1.5 の差がある。同様な現象は一つの本震余震系列内に もみられ，本震と最大余震の間 Magnitude の差は 1
1.2 とされている。上述のような現象は地震源の階層性 によって定量的に説明できる。階層モデルにおいて，地 震源の破壊過程は図一 2 に示したように段階的なものか らなると仮定する10)。まず，ある代表的な長さを持った 破壊要素がある確率で 1 個, 2 個，‥と拡大し停止する。 これがある数以上に拡大し合体すると，1 まわり大きな スケールを持った破壊へ成長する。そしてこの繰り返し によって，震源全体の破壊まで達する。

一般に, Double couple force 震源による地表面の応 答は式（1）のように地震モーメントとグリーン関数の Convolution として表せる ${ }^{11}$. 震源過程は時間的空間的 に分布する小イベントからなるとする。Inversion 法を 用い，長周期地震波からその時空間分布を決める。その 解を階層モデルの第一階層要素とする。 $\alpha$ が下の階層と 上の階層の要素間長さ比とすると, $k$ 番目の階層は, パ ルス幅が $\alpha^{k-1}$ 倍, 地震モーメントが $\alpha^{3(k-1)}$ 倍の $\alpha^{-2(k-1)}$ 個要素からなる。各要素の破壊開始時刻は仮定した破壊 伝播パターンから分かる。最後に, 合成波形は式 $(8)$ のように求められる。

\section{1989 伊豆半島東方沖地震のシミュレーション}

点震源に対して, 階層モデルの各階層のパラメータは 表一1のように決定できる。係数 $(1-\alpha)$ は地震モーメ ントを 1 にするためのものである。モーメント速度，加 速度，第 3 次微分の時刻歴とFourier spectra を図一3 に示す。それぞれは遠地地動変位, 速度, 加速度に対応 するものである。なお，モーメント速度関数は継続時間 6 秒を有する cosine 型のものとし, 破壊伝播パターンは ランダムとした。

1989 伊豆半島東方沖地震の観測点と震源メカニズム は図一4に示す。解析には, 東京大学地震研究所 ${ }^{(4)}$ が所 有の SOF とITO二観測点で記録した加速度波形を使 用した。速度波形は記録された加速度波形を積分して求 めた。加速度波形はゼロ線補正を行った後, チェビシェ フ型バンドパスフィルタをほどこした。その際, 用いた パラメータは $f_{l}=0.1 \mathrm{~Hz}, f_{h}=10 \mathrm{~Hz}, f_{s}=15 \mathrm{~Hz}$ 。線形 加速度法によって得られた速度波形も $f_{l}=0.1 \mathrm{~Hz}, f_{h}$ $=0.5 \mathrm{~Hz}, f_{s}=2 \mathrm{~Hz}$ となるフィルタをかけた。いずれ のフ.ィルタにおいても遮断帯でのパワーを $52 \mathrm{~dB} と し$ た。

表一 2 に気象庁と防災科学技術研究所が発表した震源 パラメータを示す。表一 3 にグリーン関数を計算するた めの地盤定数を示す。モーメント速度関数は図一 3 と同 じものを用いた。ただし，継続時間は 1.5 秒とした。 
図一 5 に，速度波形から，反復回数 2 回の Inversion 結果を示してある。断層のパラメータは波形の主要動に よって決められるので, 合成波形と観測波形の $P$ 波初 動は合わない場合がある。結果全体をみると，EW 方 向成分は大きな振幅を有しており，よい対応を示してい るといえる。また Fourier spectra の場合は，全成分に おいてよい対応がみられる。

加速度波形は，速度波形から微分したもので，階層モ デルの第一階層によるものでもあるので, Inversion の 結果によるところが大きいと推測できる。階層モデルの パラメータである階層階数, 階層要素長さ比亡破壊伝播 パターンによる影響を検討した結果は図一 6 と図一7に 示してある。時刻歴は長さ比を $1 / 2,1 / 3,1 / 4$, 階層階 数を 2 か 3 としたものである。階層階数は Nyquist 振 動数之解析対象振動数によって決められる。スペクトル は階層階数の増加につれ大きくなるので, 図には階層階 数が 3 のケースだけ示してある。

記録波形と比べると，合成波形は全体的に小さく， Fourier spectraも $1.5 \mathrm{~Hz}$ まで再現できたものの，原波 形の複雑さを再現できなかった。一般に, 時刻歴の振幅 の大きさは要素間長さ比と比例するので, 長さ比が $1 / 2$ のとき最大振幅となった。長さ比が $1 / 4$ になると，ほぼ 第 1 階層のものと同じレベルになった。

破壊伝播パターンが円形と仮定した場合，階層階数が 3 , 長さ比が $1 / 3$ のとき, 合成波形の時刻歴は観測值と よく一致する。Fourier spectraの場合は, SOFにおい て長さ比が $1 / 2$ か $1 / 3$ のき, ITOにおいて長さ比が $1 / 4$ のとき，合成波形は観測値とよく一致する。破壊伝 播パターンがランダムと仮定した場合, 階層階数が 3 , 長さ比が $1 / 3$ のとき，合成波形の時刻歴は観測值とよく 一致する。Fourier spectra の場合は, 長さ比が $1 / 2$ の
とき, 合成波形は観測值とよく一致する。全体の最適パ ラメータは階層モデルのパラメータである階層階数, 階 層要素長さ比と破壊伝播パターンを調整することによっ て得られるであろう。

\section{4. 結 論}

（1）時間と振動数領域において断層モデルを用いた広 帯域地震動の作成法について更に検討した。階層モデル は地震源の不均一性, “不連続性に加えて, 階層性も考慮 したものである。階層モデルは1）応力降下量 2) 断層 面の大きさ3）サブイベントの時空間分布 4) 階層階数 と階層要素間長さ比などによって特性づけられる。具体 的には, Inversion 法を用いて, 長周期地震波から震源 過程の時空間分布を決めたうえ，これを最上部階層とす る階層モデルによって広帯域地震動を合成する。 （2）このモデルを用いて，1989 年 7 月 9 日伊豆半島東 方沖地震 $\left(M_{J}=5.5\right)$ についてシミュレーションを行っ た。さらに, 最大値, 継続時間, スペクトル特性などに ついて, 階層モデルのパラメータである階層階数, 階層 要素長さ比と破壊伝播パターンによる影響を検討した。 1. $0 \mathrm{~Hz}$ までの速度波形からの Inversion 結果を用い, 加 速度波形について, $4.0 \mathrm{~Hz}$ までの Fourier spectra と最 大値，継続時間をよく再現できた。

（3）一般に，Backward 問題においては，Fourier spectra から階層モデルのパラメータは決められる。そ の最大ピークが起こる振動数と 2 番目最大ピークが起こ る振動数の比によって,階層要素間長さ比は決められる。 そのピーク比によって, 破壊伝播パタンンは推定できる。 今後, 階層モデルを実用化するために, 各種規模の地震 について階層性を検討する必要がある。 